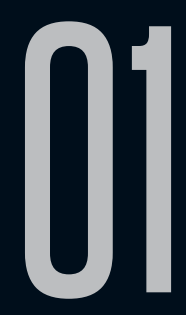

\title{
DAS UNHEIMLICHE OU "O ESTRANHO", DE FREUD
}

Lenice Alves Soares (UERJ)

Recebido em 24 abr 2019. Lenice Alves Soares é Mestranda em Teoria Aprovado em 18 jul 2019. da Literatura e Literatura Comparada pela UERJ, Psicanalista e Especialista em Psicologia Transdisciplinar Holística pela FSJT e UNIPAZ-Rio (2015), Especialista no Ensino de Alemão como Língua Estrangeira pela UFBA e Universidade de Kassel-Alemanha (2005), Especialista em Língua e Literatura alemã pela UFRJ (2000) e é Licenciada em Letras Português-Alemão pela UFF (1992). Atua como professora de alemão (ICG) e Terapeuta holística (CRT 49333). Lattes: http://lattes.cnpq. br/3215484032184593 E-mail: leniceicg@terra.com.br

Resumo: Sigmund Freud publica, em 1919, um texto intitulado Das Unheimliche (O estranho/O inquietante), com a intenção de mostrar a causa do sentimento de estranheza nos seres humanos, tendo como base o conto $O$ homem da areia, do autor alemão E. T. A. Hoffmann. O presente artigo tem como objetivo fazer um resumo comentado deste texto de Freud e mostrar a importância do mesmo para a teoria da ficção fantástica.

Palavras-chave: O estranho; Complexo de castração; Psicanálise; Estudos literários; Ficção fantástica; $O$ homem da areia. 
Zusammenfassung: Sigmund Freud veröffentlicht 1919 einen Text, dessen Titel Das Unhemliche heisst, mit der Absicht die Ursache des Gefühls des Unheimlichen in den Menschen zu zeigen, indem er die Erzählung Der Sandmann des deutschen Autors E. T. A. Hoffmann als Grundlage hat. Der beiliegende Artikel verfolgt das Ziel, eine kommentierte Zusammenfassung des freudischen Textes zu machen und dessen Wichtigkeit für die fantastische Fiktion zu zeigen.

Schlüsselwörter: Das Unheimliche; Kastrationskomplex; Psychoanalyse; Literaturwissenschaft; Fantastische Fiktion; Der Sandmann.

Antes da publicação do ensaio intitulado Das Unheimliche, em fins de 1919, Sigmund Freud (1856-1939) ${ }^{1}$ menciona seu conteúdo numa carta de 12 de maio do mesmo ano ao seu colaborador, o médico e psicanalista húngaro Sándor Ferenczi (1873-1933)², dizendo que está reescrevendo "um velho texto". Pelo estudo de sua obra, sabe-se que o tema do referido ensaio "já estava presente em sua mente em 1913" (FREUD, 1976, p.275). Na mesma carta, Freud menciona que um rascunho de Além do princípio de prazer, publicado em 1920, estaria concluído. Das Unheimliche, traduzido inicialmente para o português como $O$ estranho, e Além do princípio de prazer são textos que, de certa forma, dialogam entre si. Embora o segundo seja considerado, no conjunto de sua obra, mais importante, o primeiro também lança ideias de suma relevância para a teoria psicanalítica.

O estranho (1976), também conhecido como $O$ inquietante $(2010)^{3}$, publicado primeiramente em 1919, está completando,

$1 \quad$ Sigmund Freud ( $\star$ 1856- +1939 )

2 Sándor Ferenczi ( $\star$ 1873-† 1933).

3 O tradutor chama a atenção em nota para a "insuficiência da tradução desse termo", "por razões que ficarão evidentes no próprio texto" (FREUD, 2010, p.329). 
portanto, cem anos, e é mencionado, ao longo desse tempo, por inúmeros estudiosos, tanto da área da Psicanálise quanto dos Estudos Literários, sendo algumas noções e conceitos ali apresentados muito caros a ambas as áreas do conhecimento, como o duplo, a repetição (ou compulsão à repetição) e o complexo de castração, além do próprio termo que dá título ao estudo. 0 texto tem destaque especial na teoria, na crítica e na historiografia literárias da ficção fantástica, em grande parte, por Freud ter lançado mão de um texto literário para exemplificar sua teoria sobre o estranho. 0 conto $O$ homem da areia, do autor alemão Ernst Theodor Amadeus Hoffmann (2012) (1776-1822) ${ }^{4}$, publicado praticamente cem anos antes do texto de Freud, tem papel de destaque no ensaio do pai da Psicanálise.

Esse ensaio de Freud se tornou tão relevante para os Estudos Literários que há o verbete "inquietante estranheza (das Unheimliche)" no E-Dicionário de Termos Literários, de Carlos Ceia. E a relevância do escrito se torna ainda mais acentuada quando levamos em consideração os estudos acerca da ficção fantástica, nos quais ele é repetidamente mencionado. Como exemplo disso, podemos citar a obra considerada básica nos estudos do fantástico, Introdução à literatura fantástica, de Tzvetan Todorov (1992), publicada primeiramente em 1970, e a obra de Ana Luiza Silva Camarani (2014), A literatura fantástica: caminhos teóricos, onde a autora faz um trabalho de levantamento acerca das reflexões teóricas e críticas sobre a literatura fantástica ao longo do tempo. Nessa obra verificamos que inúmeros teóricos contemplados pela autora mencionam o texto de Freud, objeto deste artigo. Utilizo aqui tanto a edição da Editora Imago, de 1976, com tradução de 
Jayme Salomão a partir das obras completas de Freud em inglês (Standard Edition), quanto a edição da Editora Companhia das Letras, de 2010, com tradução de Paulo César Lima de Souza direto da edição em alemão.

No início do referido ensaio, Freud justifica seu interesse pelo campo da estética, o qual ele entende não como "simplesmente a teoria da beleza, mas a teoria das qualidades do sentir" e que o psicanalista ocasionalmente "tem de interessar-se por algum ramo particular" dessa área, o qual revela-se, geralmente, "um campo bastante remoto, negligenciado na literatura especializada da estética", e "o tema do 'estranho' é um ramo desse tipo" (1976, p.276). Assim, ele explica que:

Nada em absoluto encontra-se a respeito deste assunto em extensos tratados de estética, que em geral preferem preocupar-se com o que é belo, atraente e sublime - isto é, com sentimentos de natureza positiva - e com as circunstâncias e os objetivos que os trazem à tona, mais do que com os sentimentos opostos, de repulsa e aflição. Conheço apenas uma tentativa na literatura médico-psicológica, um artigo fértil, mas não exaustivo, de Jentsch (1906). Mas devo confessar que não fiz um exame muito completo da literatura relacionada com esta minha modesta contribuição, particularmente da literatura estrangeira, por razões que, como pode ser facilmente adivinhado, estão nos tempos em que vivemos; de forma que meu artigo é apresentado ao leitor sem qualquer pretensão de prioridade. (FREUD, 1976, p.276)

Como mencionado, pode-se afirmar que Freud já teria se ocupado com o tema do estranho (das Unheimliche) em 1913, 
ou seja, antes da Primeira Guerra Mundial (1914-1918), mas só veio a publicá-lo após o término do conflito. São estes os tempos mencionados por ele, e que, certamente, influenciaram a sua decisão de retirar da gaveta o "velho texto" e reescrevê-lo, sob a ótica dos últimos acontecimentos vivenciados pelo mundo, sobretudo na Europa.

Ele se questiona a respeito do estranho, tema, segundo ele, negligenciado na literatura específica sobre a estética, ou melhor, ele indaga a que o estranho estaria relacionado. E aqui cito as duas traduções, com grifos meus, para chamar atenção para a escolha do léxico específico por parte de cada um dos tradutores:

O tema do "estranho" é um ramo desse tipo. Relaciona-se indubitavelmente com o que é assustador - com o que provoca medo e horror; certamente, também, a palavra nem sempre é usada num sentido claramente definível, de modo que tende a coincidir com aquilo que desperta 0 medo em geral. Ainda assim, podemos esperar que esteja presente um núcleo especial de sensibilidade que justificou o uso de um termo conceitual peculiar. Fica-se curioso para saber que núcleo comum é esse que nos permite distinguir como "estranhas" determinadas coisas que estão dentro do campo do que é amedrontador. (FREUD, 1976, p.276 - grifo nosso)

"O inquietante" é um desses domínios. Sem dúvida, relaciona-se ao que é terrível, ao que desperta angústia e horror, e também está claro que o termo não é usado sempre num sentido bem determinado, de modo que geralmente equivale ao angustiante. É lícito esperarmos, no entanto, que exista um núcleo especial [de significado] que justifique o uso de um termo conceitual específico. 
Gostaríamos de saber que núcleo comum é esse, que talvez permita distinguir um "inquietante" no interior do que é angustiante. (FREUD, 2010, p.329330 - grifo nosso)

Embora entenda que a segunda tradução seja mais adequada ao público, tanto leitor leigo quanto leitor crítico ou acadêmico da ficção fantástica especificamente - talvez pelo fato de o tradutor ser da área de Letras -, tendo a priorizar a primeira tradução no âmbito deste artigo, por considerá-la mais neutra, ou, em alguns momentos, mais próxima do campo psicanalítico, ou, pelo menos, do que acredito que Freud quisesse expressar na época de sua escrita. Sempre ressaltando o grande desafio que suscita a arte de traduzir, e a excelente qualidade de ambas as traduções, recorrerei, quando julgar necessário, ao texto original em alemão ${ }^{5}$.

Vale ressaltar que, além da palavra que dá título ao artigo, Das Unheimliche, (O estranho/O inquietante), a palavra Angst e seus derivados, se tornam de difícil tradução no contexto desse artigo, pois podem significar tanto medo quanto angústia.

Freud concorda com seu colega médico psiquiatra alemão, Ernst Anton Jentsch ${ }^{6}$, que exista uma variação muito grande de pessoa para pessoa, com relação à sensibilidade para o que seja estranho, mas afirma que há, contudo, "exemplos nos quais a qualidade em questão será reconhecida sem hesitações pela maioria das pessoas" 5 es zum Schreckhaften, Angst- und Grauenerregenden gehört, und ebenso sicher ist es, daß dies Wort nicht immer in einem scharf zu bestimmenden Sinne gebraucht wird, so daß es eben meist mit dem Angsterregenden überhaupt zusammenfällt. Aber man darf doch erwarten, daß ein besonderer Kern vorhanden ist, der die Verwendung eines besonderen Begriffswortes rechtfertigt. Man möchte wissen, was dieser gemeinsame Kern ist, der etwa gestattet, innerhalb des Ängstlichen ein "Unheimliches" zu unterscheiden. (FREUD, 1919 - grifo nosso).

Ernst Anton Jentsch («1867- 11919$)$. 
(1976, p.276). Para ele há dois caminhos para se encontrar exemplos de situações onde surge o sentimento do estranho:

Podemos descobrir que significado veio a ligar-se à palavra "estranho" no decorrer da sua história; ou podemos reunir todas aquelas propriedades de pessoas, coisas, impressões sensórias, experiências e situações que despertam em nós o sentimento de estranheza, e inferir, então, a natureza desconhecida do estranho a partir de tudo o que esses exemplos têm em comum. (FREUD, 1976, p.276-277)

Freud conclui, então, que ambos os caminhos conduzem ao mesmo resultado: "O estranho é aquela categoria do assustador que remete ao que é conhecido, de velho, e há muito familiar." (1976, p.277). Contudo, veremos a seguir como o médico vienense chegou a tal conclusão, exposta em seu ensaio. Ele também explica que em sua investigação coletou primeiro casos individuais, e somente depois partiu para um exame do uso linguístico para sua confirmação. Neste artigo, porém, procederá de forma inversa, optando por começar com o estudo linguístico, para depois apresentar seus estudos de casos.

Após fazer um estudo etimológico da palavra unheimlich, que em sua raiz contém a palavra Heim, que significa lar em alemão, o autor conclui que o adjetivo heimlich se refere a tudo o que é doméstico, familiar, conhecido. Contudo, acrescenta também um outro significado, pois tudo o que deve ficar no âmbito do lar e da família, deve ser ou deve ficar secreto. Portanto, com o prefixo un-, de negação, unheimlich é tudo o que não é familiar, não é conhecido, portanto, estranho, mas também tudo aquilo que não fica secreto, 
ou seja, que vem à tona. Todos esses usos são atestados no ensaio de Freud por inúmeros exemplos, literários e não literários, de uso na língua alemã. Portanto, há todo um trabalho filológico que fundamenta a sua investigação, além da comparação com a tradução da palavra para outras línguas, o que o autor credita e agradece a Theodor Reik? .

Ao final do excerto, Freud chama a atenção para a ambiguidade da palavra:

O que mais nos interessa nesse longo excerto é descobrir que entre os seus diferentes matizes de significado a palavra "heimlich" exibe um que é idêntico ao seu oposto, "unheimlich". Assim, o que é heimlich vem a ser unheimlich. [...] Em geral, somos lembrados de que a palavra "heimlich" não deixa de ser ambígua, mas pertence a dois conjuntos de idéias que, sem serem contraditórias, ainda assim são muito diferentes: por um lado significa o que é familiar e agradável e, por outro, o que está oculto e se mantém fora da vista. "Unheimlich" é habitualmente usado, conforme aprendemos, apenas como o contrário do primeiro significado de "heimlich", e não do segundo. [...] Por outro lado, percebemos que Schelling diz algo que dá um novo esclarecimento ao conceito do Unheimlich, para o qual certamente não estávamos preparados. Segundo Schelling, unheimlich é tudo o que deveria ter permanecido secreto e oculto mas veio à luz. (FREUD, 1976, p.279-280)

Assim, Freud encerra a primeira parte do seu artigo, não só chamando a atenção para a ambiguidade da palavra, como também para a importância da ideia do filósofo romântico alemão 
Friedrich Wilhelm Joseph von Schelling ${ }^{8}$ para a sequência de seu raciocínio, desenvolvido no artigo. Vale a pena mencionar que existem hoje algumas críticas a respeito de Freud ter deslocado o texto de Schelling do seu sistema original de referência, e tê-lo interpretado de outra forma (CARVALHO, 2011). Entretanto, não entrarei no mérito dessa questão, para não fugir do escopo do presente trabalho.

Dessa forma, heimlich é uma palavra cujo significado se desenvolve na direção da ambivalência, até que finalmente coincide com o seu oposto, unheimlich. Unheimlich é, de um modo ou de outro, uma subespécie de heimlich. Tenhamos em mente essa descoberta, embora não possamos ainda compreendê-la corretamente, lado a lado com a definição de Schelling do Unheimlich. Se continuarmos a examinar exemplos individuais de estranheza, essas sugestões tornarse-ão inteligíveis a nós. (FREUD, 1976, p.281)

É o que ele faz na segunda parte de seu artigo: Freud segue sua linha de raciocínio e se dedica a fazer um apanhado de exemplos de situações que suscitem o sentimento de estranheza. Retorna ao trabalho de Jentsch, cujas ideias tomará como ponto de partida para suas próprias investigações. Assim, começa citando os exemplos do colega, que menciona como situações, que geram o sentimento do estranho, a dúvida quanto a saber se um ser, aparentemente animado, estaria realmente vivo, ou se um objeto sem vida poderia estar animado, e acrescenta a estranheza causada por acessos epiléticos e manifestações de insanidade. Freud credita a Jentsch a lembrança de que o escritor 
E. T. A. Hoffmann (2012) teria empregado repetidas vezes, e com êxito, tal artifício psicológico em suas narrativas fantásticas, com o intuito de deixar o leitor na incerteza.

Escreve Jentsch: "Ao contar uma história, um dos recursos mais bem-sucedidos para criar facilmente efeitos de estranheza é deixar o leitor na incerteza de que uma determinada figura na história é um ser humano ou um autômato, e fazê-lo de tal modo que a sua atenção não se concentre diretamente nessa incerteza, de maneira que não possa ser levado a penetrar no assunto e esclarecê-lo imediatamente. Isto, como afirmamos, dissiparia rapidamente o peculiar efeito emocional da coisa. E. T. A. Hoffmann empregou repetidas vezes, com êxito, esse artifício psicológico nas suas narrativas fantásticas." (JENTSCH Apud FREUD, 1976, p.281 grifo nosso)

Jentsch adianta, cerca de sessenta anos antes, o que Todorov (1992) escreve em Introdução à literatura fantástica a respeito do momento de incerteza que instaura o fantástico na obra:

O fantástico ocupa o tempo desta incerteza. Assim que se escolhe uma das duas respostas, deixa-se o terreno do fantástico para entrar em um gênero vizinho: o estranho ou o maravilhoso. O fantástico é a vacilação experimentada por um ser que não conhece mais que as leis naturais, frente a um acontecimento aparentemente sobrenatural. (TODOROV, 1992, p.15-16)

Aqui também é inevitável associar à noção de hesitação, que, para Todorov (1992), instaura o fantástico na obra, já que Jentsch menciona a incerteza como efeito emocional no leitor -e não nos cabe aqui entrar na discussão a respeito de que leitor fala Jentsch. 
Só que Freud pretende ir além das observações de Jentsch, já que admite que Hoffmann (2012) emprega esse artifício, sobretudo em seu conto $O$ homem da areia com a personagem da boneca Olímpia, a qual dá ao texto o efeito de estranheza, porém afirma não ser esse nem o único, nem o mais importante elemento que confere tal efeito à obra, mas sim o próprio tema que dá nome ao conto: $\mathrm{O}$ "Homem da Areia" que sempre retorna em momentos decisivos da história.

Essa observação, indubitavelmente correta, refere-se principalmente à história de "O Homem da Areia", em Nachtstücke, de Hoffmann, que contém o original de Olímpia, a boneca que aparece no primeiro ato da ópera de Offenbach, Contos de Hoffmann. Mas não posso achar - e espero que a maioria dos leitores da história concorde comigo - que o tema da boneca Olímpia, que é em todos os aspectos um ser humano, seja de alguma forma o único elemento, ou de fato o mais importante, a que se deva atribuir a inigualável atmosfera de estranheza evocada pela história. Nem essa atmosfera é elevada pelo fato de que o próprio autor trata o episódio de Olímpia com um leve toque de sátira e o usa para ridicularizar a idealização que o jovem faz da sua amante. 0 tema principal da história é, pelo contrário, algo diferente, algo que lhe dá o nome e que é sempre reintroduzido nos momentos críticos: é o tema do "Homem da Areia", que arranca os olhos das crianças. (FREUD, 1976, p.281)

Em seguida, Freud faz um resumo do conto de Hoffmann (2012) para poder falar do que é, para ele, o principal tema que confere ao texto o efeito de estranhamento, a saber, a figura do Homem da Areia, que arranca os olhos das crianças. É interessante seguir o 
percurso de Freud em seu ensaio, pois juntamente com seu resumo, ele começa a direcionar para sua própria interpretação do estranho.

O jovem estudante Nataniel relata em uma carta a seu amigo Lothar, e também irmão de sua noiva Clara, o encontro que teve há poucos dias com um vendedor de barômetros, Giuseppe Coppola, que ele acredita ser o advogado Coppelius, ao qual ele imputa a morte de seu pai, que ocorrera na sua infância, e com o qual ele associa a figura do Homem da Areia. Assim resume Freud o início da história:

Esse conto fantástico principia com as recordações de infância do estudante Nataniel. A despeito da sua felicidade presente, não pode banir as lembranças ligadas à morte misteriosa e apavorante do seu amado pai. Em certas noites, sua mãe costumava mandar as crianças cedo para a cama, prevenindo-as de que "o Homem da Areia estava chegando"; e, por certo, Nataniel não deixaria de ouvir os pesados passos de um visitante, com o qual o pai estaria ocupado toda a noite. Quando indagada acerca do Homem da Areia, a sua mãe na verdade negava que tal pessoa existisse, exceto como figura de linguagem; a babá, porém, podia dar-Ihe uma informação mais precisa: "É um homem perverso que chega quando as crianças não vão para a cama, e joga punhados de areia nos olhos delas, de modo que estes saltam sangrando da cabeça. Ele coloca então os olhos num saco e os leva para a meia-lua, para alimentar os seus filhos. Eles estão acomodados lá em cima, no ninho, e seus bicos são curvos como bicos de coruja, e eles os usam para mordiscar os olhos dos meninos e das meninas desobedientes." (FREUD, 1976, p.282 - grifo nosso) 
O pequeno Nataniel, já com dez anos, se esconde depois do jantar para tentar descobrir quem é o homem que visita o seu pai à noite, é descoberto pelo advogado Coppelius, temido pelas crianças da família, tem uma experiência traumática e associa a morte de seu pai, um ano depois, à presença de Coppelius, a quem ele liga diretamente a história do Homem da Areia. Freud prossegue com o resumo do texto, mas é interessante continuar a atentar para suas observações - com grifos nossos -, as quais, como dito, já remetem para a sua interpretação do conto, e do que, para ele, estaria relacionado ao sentimento do estranho:

Embora o pequeno Nataniel fosse sensível e tivesse idade bastante para não dar crédito à figura do Homem da Areia com tais horríveis atributos, ainda assim o medo fixou-se no seu coração. Determinou-se a descobrir que aparência tinha o Homem da Areia; e uma noite, quando o Homem da Areia era outra vez esperado, ele escondeu-se no escritório do pai. Reconheceu o visitante como sendo o advogado Copélio, uma pessoa repulsiva que amedrontava as crianças quando, ocasionalmente, aparecia para jantar; e ele agora identificava esse Copélio com o temido Homem da Areia. No que diz respeito ao resto da cena, Hoffmann já nos deixa em dúvida se o que estamos testemunhando é o primeiro delírio do apavorado menino, ou uma sucessão de acontecimentos que devem ser considerados, na história, como sendo reais. O pai e o convidado estão trabalhando num braseiro incandescente. $\mathbf{0}$ pequeno intrometido ouve Copélio invocar: "Aqui os olhos! Aqui os olhos!", e trai-se ao soltar um alto grito. Copélio apanha-o e está prestes a lançar brasas tiradas do fogo em seus olhos, jogando estes depois no braseiro, mas o pai lhe implora que 
solte o menino e salva-lhe os olhos. Depois disso, o rapaz cai em profundo desfalecimento; e uma longa enfermidade põe fim à sua experiência. Aqueles que optam pela interpretação racionalista do Homem da Areia não deixam de reconhecer, na fantasia do menino, a persistente influência da história contada pela babá. Os punhados de areia que deveriam ser jogados aos olhos da criança, transformam-se em pedaços de carvão em brasa, tirados das chamas; e em ambos os casos destinam-se a fazer com que os seus olhos pulem para fora. No decorrer de uma outra visita do Homem da Areia, um ano depois, o pai é morto no escritório por uma explosão. $\mathrm{O}$ advogado Copélio desaparece do lugar sem deixar qualquer vestígio atrás de si. (FREUD, 1976, p.282 - grifo nosso)

Nataniel, já adulto e morando como estudante em outra cidade, continua em sua carta ao amigo Lothar, com o relato sobre o encontro com o vendedor Coppola, que ele acredita ser Coppelius. Vale ressaltar que, para Freud, o fato do conto começar em forma de cartas e ter, portanto, um determinado narrador e um narratário, os quais depois mudam no decorrer da narrativa, é irrelevante para sua linha de raciocínio. Freud prossegue com seu resumo e comentários a respeito:

Nataniel, agora um estudante, crê ter reconhecido esse fantasma de horror da sua infância num oculista itinerante, um italiano chamado Giuseppe Coppola, que na cidade universitária, se oferece para vender-lhe barômetros. Quando Nataniel recusa, o homem prossegue: "Não quer barômetros? Não quer barômetros? Tenho também ótimos olhos, ótimos olhos!" O terror do estudante atenua-se quando descobre que os olhos oferecidos são apenas inofensivos óculos, 
e compra um pequeno telescópio de Coppola. Com a ajuda do instrumento ele observa a casa em frente, do professor Spalanzani, e ali espia a bela mas estranhamente silenciosa e imóvel filha de Spalanzani, Olímpia. Logo se apaixona por ela tão violentamente que, por sua causa, esquece a moça talentosa e sensível de quem está noivo. Mas Olímpia é um autômato, cujo mecanismo foi feito por Spalanzani e cujos olhos foram colocados por Coppola, o Homem da Areia. O estudante surpreende os dois Mestres discutindo quanto ao seu trabalho manual. O oculista leva embora a boneca de madeira, sem os olhos; e o mecânico, Spalanzani, apanha no chão os olhos sangrentos de Olímpia e os arremessa ao peito de Nataniel, dizendo que Coppola os havia roubado do estudante. Nataniel sucumbe a um novo ataque de loucura e, no seu delírio, a recordação da morte do pai mistura-se a essa nova experiência. "Apressa-te! Apressa-te! anel de fogo!" grita ele. "Gira, anel de fogo - Hurrah! Apressa-te, boneca de pau! Linda boneca de pau, gira -." Cai então sobre o professor, o "pai" de Olímpia, e tenta estrangulá-lo. (FREUD, 1976, p.282-283 - grifo nosso)

Vale a pena mencionar que na parte anterior Freud ainda deixa em aberto quanto a ser um delírio do menino ou acontecimentos reais, e agora denomina como ataque de loucura. Freud prossegue com a última parte de seu resumo e comentários:

Reanimando-se de uma longa e grave enfermidade, Nataniel parece, por fim, estar recuperado. Pretende casar-se com a sua noiva, com a qual se reconciliou. Um dia estavam ele e ela passeando pelo mercado da cidade, sobre o qual a alta torre da prefeitura lança a sua enorme sombra. Por sugestão da moça, sobem à torre, deixando em 
baixo o irmão dela, que caminhava com eles. Do alto, a atenção de Clara é atraída para um curioso objeto que se move ao longo da rua. Nataniel observa essa coisa através do telescópio de Coppola e cai num novo ataque de loucura. Gritando "Gira, boneca de pau!", tenta jogar a garota da torre. $\mathrm{O}$ irmão da moça, levado pelos gritos desta, salva-a e apressa-se em descer com ela em segurança. Lá em cima, na torre, o louco corre em círculos berrando "Gira, anel de fogo!" - e nós sabemos a origem das palavras. Entre as pessoas que começaram a se juntar em baixo, destaca-se a figura do advogado Copélio, que voltou de repente. Podemos supor que foi a sua aproximação, vista através do telescópio, que lançou Nataniel ao seu acesso de loucura. Enquanto as pessoas que observam a cena se preparam para subir e dominar o louco, Copélio ri e diz: "Esperem um pouco; ele vai descer por si próprio." Subitamente Nataniel fica imóvel, avista Copélio e, com um grito selvagem de "Sim! Ótimos olhos - ótimos olhos!", lança-se por sobre o parapeito. Seu corpo jaz nas pedras da rua com o crânio despedaçado, enquanto o Homem da Areia desaparece na multidão. (FREUD, 1976, p.283 grifo nosso)

Freud conclui aqui seu resumo do conto e retoma as observações de Jentsch, para levantar sua própria teoria a respeito do sentimento do estranho:

Esse breve sumário não deixa dúvidas, acho eu, de que o sentimento de algo estranho está ligado diretamente à figura do Homem da Areia, isto é, à idéia de ter os olhos roubados, e que o ponto de vista de Jentsch, de uma incerteza intelectual, nada tem a ver com o efeito. A incerteza quanto a um objeto ser vivo ou inanimado, que reconhecidamente se aplica à boneca Olímpia, é algo irrelevante em 
relação a esse outro exemplo, mais chocante, de estranheza. É verdade que o escritor cria uma espécie de incerteza em nós, a princípio, não nos deixando saber, sem dúvida propositalmente, se nos está conduzindo pelo mundo real ou por um mundo puramente fantástico, de sua própria criação. Ele tem, de certo, o direito de fazer ambas as coisas; e se escolhe como palco da sua ação um mundo povoado de espíritos, demônios e fantasmas, como Shakespeare em Hamlet, em Macbeth e, em sentido diferente, em A Tempestade e Sonho de uma Noite de Verão, devemo-nos curvar à sua decisão e considerar o cenário como sendo real, pelo tempo em que nos colocamos nas suas mãos. Essa incerteza, porém, desaparece no decorrer da história de Hoffmann, e percebemos que pretende, também, fazer-nos olhar através dos óculos ou do telescópio do demoníaco oculista - talvez, na verdade, o próprio autor em pessoa tenha feito observações atentas através de tal instrumento. A conclusão da história deixa bastante claro que Coppola, o oculista, é realmente o advogado Copélio e também, portanto, o Homem da Areia. (FREUD, 1976, p.283284 - grifo nosso)

Freud considera a teoria da incerteza intelectual, levantada por Jentsch, somente com relação à dúvida se Olímpia é um ser animado ou não. Essa incerteza, que para Jentsch suscita o sentimento de estranho no texto, é considerada por Freud irrelevante, frente à figura do Homem da Areia. De certa forma, Freud desvincula ambas as figuras, as quais, na narrativa, estão intrinsecamente ligadas pelo motivo dos olhos que permeia todo o texto e traz uma unidade à narrativa. Não só o Homem da Areia, mas também a figura de Olímpia contribuem para que o insólito se instaure na narrativa, 
e seja percebido, seja em forma de experiência emocional, com a hesitação, segundo Todorov (1992), ou de experiência intelectual, com a incerteza, segundo Bessière (1974), ou de ambiguidade, segundo Felipe Furtado (1980), que coloca ênfase na estrutura textual e na fenomenologia metaempírica.

É claro que Freud não entra em todos esses detalhes, que foram elaborados ao longo do tempo pelos teóricos da ficção fantástica, mas os tangencia na sua procura pelo que causa o sentimento do estranho na narrativa de Hoffmann (2012). Seu foco está na recepção da obra, sobre o efeito do estranho, sem pensar a respeito da estrutura textual de forma profunda, nem sequer em fazer a diferença entre autor e narrador(es), ou entre leitor e narratário(s). Embora Freud afirme que a incerteza desaparece no decorrer do conto, considero este parágrafo, assim como o seguinte, peças chave para associações com teorias da ficção fantástica, que procuraram dar conta do que a caracterizaria.

Prossigamos com Freud em seu percurso:

Não se trata aqui, portanto, de uma questão de incerteza intelectual: sabemos agora que não devemos estar observando o produto da imaginação de um louco, por trás da qual nós, com a superioridade das mentes racionais, estamos aptos a detectar a sensata verdade; e, ainda assim, esse conhecimento não diminui em nada a impressão de estranheza. A teoria da incerteza intelectual é, assim, incapaz de explicar aquela impressão. (FREUD, 1976, p.284)

A "sensata verdade", que nós, "com a superioridade das mentes racionais, estamos aptos a detectar" é, para Freud, condizente com 
os estudos do campo psicanalítico, desenvolvidos por ele e seus pares no início do século passado. Afinal, este é o seu campo de investigação, e foco nos comentários concernentes ao texto. Assim, ele prossegue:

Sabemos, no entanto, pela experiência psicanalítica, que o medo de ferir ou perder os olhos é um dos mais terríveis temores das crianças. Muitos adultos conservam uma apreensão nesse aspecto, e nenhum outro dano físico é mais temido por esses adultos do que um ferimento nos olhos. Estamos acostumados, também, a dizer que estimamos uma coisa como a menina dos olhos. O estudo dos sonhos, das fantasias e dos mitos ensinou-nos que a ansiedade em relação aos próprios olhos, o medo de ficar cego, é muitas vezes um substituto do temor de ser castrado. $\mathrm{O}$ autocegamento do criminoso mítico, Édipo, era simplesmente uma forma atenuada do castigo da castração - o único castigo que era adequado a ele pela lex tallionis. Podemos tentar, com fundamento racionalista, negar que os temores em relação aos olhos derivem do medo da castração, e argumentar que é muito natural que um órgão tão preciso como o olho deva ser guardado por um medo proporcional. Na verdade, podemos ir mais além e dizer que o próprio medo da castração não contém outro significado, nem outro segredo mais profundo, do que um justificável medo de natureza racional. Esse ponto de vista, porém, não considera adequadamente a relação substitutiva entre o olho e o órgão masculino, que se verifica existir nos sonhos, mitos e fantasias; nem dissipa a impressão de que a ameaça de ser castrado excita de modo especial uma emoção particularmente violenta e obscura, e que é essa emoção que dá, antes de mais nada, intenso colorido à idéia de perder outros órgãos. Todas as 
demais dúvidas são afastadas quando sabemos, pela análise de pacientes neuróticos, dos detalhes do seu 'complexo de castração' e compreendemos a enorme importância desse complexo na vida mental de tais pacientes. (FREUD, 1976, p.284)

Para Freud, não restam dúvidas de que o que traz o sentimento do estranho ao texto é o medo de perder os olhos, medo este, segundo ele, associado ao complexo de castração, de enorme importância na vida mental dos pacientes neuróticos. Na teoria psicanalítica, a castração "designa uma experiência psíquica completa, inconscientemente vivida pela criança por volta dos cinco anos de idade" (NASIO, 1989, p.13), a qual faz parte do desenvolvimento psicossexual do ser humano.

Vale a pena transcrever o início dos verbetes complexo e complexo de castração do Vocabulário da Psicanálise (1991):

Complexo: Conjunto organizado de representações e recordações de forte valor afetivo, parcial ou totalmente inconscientes. Um complexo constitui-se a partir das relações interpessoais da história infantil; pode estruturar todos os níveis psicológicos: emoções, atitudes, comportamentos adaptados. (LAPLANCHE; PONTALIS, 1991, p.70)

Complexo de castração: Complexo centrado na fantasia de castração, que proporciona uma resposta ao enigma que a diferença anatômica dos sexos (presença ou ausência de pênis) coloca para a criança. Essa diferença é atribuída à amputação do pênis na menina. A estrutura e os efeitos do complexo de castração são diferentes no menino e na menina. O menino teme a castração como realização de uma ameaça paterna em resposta às suas atividades sexuais, surgindo daí uma intensa angústia de castração. Na menina, a ausência do 
pênis é sentida como um dano sofrido que ela procura negar, compensar ou reparar. O complexo de castração está em estreita relação com o complexo de Édipo e, mais especialmente, com a função interditória e normativa. (LAPLANCHE; PONTALIS, 1991, p.73)

Assim, fica claro quando Freud associa o sentimento do estranho ao complexo de castração, como algo "assustador que remete ao que é conhecido, de velho, e há muito familiar" (1976, p.277), que "deveria ter permanecido secreto e oculto, mas veio à luz" (1976, p.280), pois são os temores infantis, recalcados no inconsciente, que vêm à tona em determinadas situações, como enfatiza Freud em relação ao conto de Hoffmann (2012):

Ademais, eu não recomendaria a qualquer oponente da concepção psicanalítica que escolhesse particularmente essa história do Homem da Areia, para apoiar o argumento de que a ansiedade em relação aos olhos nada tem a ver com o complexo de castração. Por que razão, então, colocou Hoffmann essa ansiedade em relação tão íntima com a morte do pai? E por que o Homem da Areia aparece sempre como um perturbador do amor? Ele separa o infeliz Nataniel da sua noiva e do irmão desta, seu melhor amigo; ele destrói o segundo objeto do seu amor, Olímpia, a linda boneca; e leva-o ao suicídio no momento em que recuperou a sua Clara e está prestes a unirse venturosamente a ela. Na história, elementos como estes e muitos outros parecem arbitrários e sem sentido, na medida em que negamos toda ligação entre os medos relacionados com os olhos e com a castração; mas tornam-se inteligíveis tão logo substituímos o Homem da Areia pelo pai temido, de cujas mãos é esperada 
a castração. Arriscar-nos-emos, portanto, a referir o estranho efeito do Homem da Areia à ansiedade pertencente ao complexo de castração da infância. Contudo, uma vez atingida a idéia de que podemos tornar um fator infantil como este responsável por sentimentos de estranheza, somos encorajados a verificar se podemos aplicá-la a outros exemplos do estranho. (FREUD, 1976, p.284-285)

Freud conclui suas reflexões inerentes ao conto de Hoffmann (2012), retornando ao exemplo da boneca Olímpia, levantado por Jentsch, como outro exemplo do estranho no texto, mas não concorda que este venha de um medo infantil, como o complexo da castração, ligado à figura do Homem da Areia:

Na história do Homem da Areia, encontramos o outro tema destacado por Jentsch, de uma boneca que parece ter vida. Jentsch acredita que se cria uma condição particularmente favorável para despertar sentimentos de estranheza, quando existe uma incerteza intelectual quanto a um objeto ter ou não vida, e quando um objeto inanimado se torna excessivamente parecido com um objeto animado. Ora, certamente as bonecas são intimamente ligadas com a vida infantil. Lembremo-nos de que, nos primeiros folguedos, de modo algum as crianças distinguem nitidamente objetos vivos de objetos inanimados, e gostam particularmente de tratar as suas bonecas como pessoas vivas. De fato, tenho ouvido ocasionalmente uma paciente declarar que, mesmo aos oito anos de idade, ainda estava convencida de que as suas bonecas certamente ganhariam vida se ela as olhasse de uma determinada forma, extremamente concentrada. De modo que, também aqui, não é difícil descobrir um fator da infância. Curiosamente, porém, ainda que a história do Homem da Areia 
aborde o despertar de um medo da primitiva infância, a idéia de uma 'boneca viva' não provoca absolutamente o medo; as crianças não temem que as suas bonecas adquiram vida, podem até desejálo. A fonte de sentimentos de estranheza não seria, nesse caso, portanto, um medo infantil; mas, antes, seria um desejo ou até mesmo simplesmente uma crença infantil. Parece haver aqui uma contradição; porém, talvez seja apenas uma complicação, que nos pode ser útil mais tarde. (FREUD, 1976, p.285)

A partir daí, o texto de Freud toma outro direcionamento, pois ele procura outros exemplos do estranho, que podem ser atribuídos a causas infantis, mas não mais no conto de Hoffmann (2012) 0 Homem da Areia, ainda que continue a mencionar outras obras do autor alemão, já que, segundo Freud, "Hoffmann é o mestre incomparável do estranho na literatura" (1976, p.285).

Assim, o tema do duplo é o próximo a ser mencionado, juntamente com o tema da repetição.

Devemo-nos contentar em escolher aqueles temas de estranheza que se destacam mais, ao mesmo tempo em que verificamos se também podem ser facilmente atribuídos a causas infantis. Todos esses temas dizem respeito ao fenômeno do 'duplo', que aparece em todas as formas e em todos os graus de desenvolvimento. Assim, temos personagens que devem ser considerados idênticos porque parecem semelhantes, iguais. Essa relação é acentuada por processos mentais que saltam de um para outro desses personagens - pelo que chamaríamos telepatia -, de modo que um possui conhecimento, sentimento e experiência em comum com o outro. Ou é marcada pelo fato de que o sujeito identificase com outra pessoa, de tal forma que fica em dúvida sobre quem é o seu eu (self), ou substitui 
o seu próprio eu (self) por um estranho. Em outras palavras, há uma duplicação, divisão e intercâmbio do eu (self). E, finalmente, há o retorno constante da mesma coisa - a repetição dos mesmos aspectos, ou características, ou vicissitudes, dos mesmos crimes, ou até dos mesmos nomes, através das diversas gerações que se sucedem. (FREUD, 1976, p.285-286)

Freud credita a Otto $\operatorname{Rank}^{9}$, outro psicanalista e psicólogo austríaco, uma pesquisa mais minuciosa sobre o duplo. Vale ressaltar que os estudos de Rank (2013) servem de base, ainda hoje, para as pesquisas sobre o tema.

O tema do 'duplo' foi abordado de forma muito completa por Otto Rank (1914). Ele penetrou nas ligações que o 'duplo' tem com reflexos em espelhos, com sombras, com os espíritos guardiões, com a crença na alma e com o medo da morte; mas lança também um raio de luz sobre a surpreendente evolução da idéia. Originalmente, o 'duplo' era uma segurança contra a destruição do ego, uma 'enérgica negação do poder da morte', como afirma Rank; e, provavelmente, a alma 'imortal' foi o primeiro 'duplo' do corpo. Essa invenção do duplicar como defesa contra a extinção tem sua contraparte na linguagem dos sonhos, que gosta de representar a castração pela duplicação ou multiplicação de um símbolo genital. O mesmo desejo levou os antigos egípcios a desenvolverem a arte de fazer imagens do morto em materiais duradouros. Tais idéias, no entanto, brotaram do solo do amor-próprio ilimitado, do narcisismo primário que domina a mente da criança e do homem primitivo. Entretanto, quando essa etapa está superada, o 'duplo' inverte seu aspecto. Depois de haver sido uma garantia 9 Otto Rank (Æ1884-\$1939). 
da imortalidade, transforma-se em estranho anunciador da morte. (FREUD, 1976, p.286)

Freud acredita ser o duplo "uma criação que data de um estádio mental muito primitivo, há muito superado" e que o ego projeta para fora esse material, "como algo estranho a si mesmo". Ele afirma ainda que "as outras formas de perturbação do ego, exploradas por Hoffmann, podem ser facilmente avaliadas pelos mesmos parâmetros do tema do 'duplo'”, ou seja, como um "retorno a determinadas fases na elevação do sentimento de autoconsideração, uma regressão a um período em que o ego não se distinguira ainda nitidamente do mundo externo e de outras pessoas", o que Freud acredita ser, em parte, responsável pela impressão de estranheza (1976, p.286-287).

Outro tema que, segundo Freud, ainda suscita a sensação do estranho é o fator da repetição. Tal fator pode ser fruto de coincidências ou superstições, que podem estar ligadas ao que ele chama de "onipotência de pensamento", que conduz à "antiga concepção animista do universo", a qual, segundo ele, remete a crenças primitivas reprimidas pelos seres humanos, que retornam em determinadas situações de vida.

É como se cada um de nós houvesse atravessado uma fase de desenvolvimento individual correspondente a esse estádio animista dos homens primitivos, como se ninguém houvesse passado por essa fase sem preservar certos resíduos e traços dela, que são ainda capazes de se manifestar, e que tudo aquilo que agora nos surpreende como 'estranho' satisfaz a condição de tocar aqueles resíduos de atividade mental animista dentro de nós e dar-Ihes expressão. (FREUD, 1976, p.289-290) 
Freud ainda menciona temas ligados ao medo da morte, à bruxaria, à epilepsia e à loucura, entre outros. Não entrarei aqui nos detalhes da explanação de Freud ao abordar os últimos temas do estranho, ou por achá-la, de certa forma, repetitiva, ou, em parte, demasiado técnica, se afastando dos textos literários que, até então, Ihe serviam como exemplos. De qualquer forma, todos os exemplos de estranho apresentados por Freud, ou remetem a "complexos infantis que haviam sido reprimidos" e "revivem uma vez mais por meio de alguma impressão", ou a "crenças primitivas que foram superadas" pelo ser humano, as quais "parecem outra vez confirmar-se" (1976, p.294).

Citando um verbete do Dicionário de psicanálise (1998), que serve como um resumo das principais ideias do ensaio de Freud:

A noção de angústia, no sentido da angústia existencial, é mais bem explicitada por Freud em textos que não versam diretamente sobre esse assunto, como "O estranho", por exemplo. Nesse texto de 1919, Freud chama de Unheimliche ("estranha familiar") a impressão assustadora que "se liga às coisas conhecidas há muito tempo e familiares desde sempre". Essa impressão de estranheza surge na vida cotidiana e na criação estética quando certos complexos infantis recalcados são abruptamente despertados. Manifesta-se então em diversos temas angustiantes: o medo da castração*, a figura do duplo, o movimento do autômato. Essas três modalidades do estranho têm como traço comum a reativação das forças primitivas que a civilização parecia ter esquecido e que o indivíduo supunha haver superado. Na figura do duplo ou do autômato, suspeita-se de que um ser aparentemente inanimado esteja vivo e se presume 
que um objeto sem vida seja animado. Quanto à angústia de castração, ela se revela nas descrições de cloacas, vampiros, membros devorados ou corpos desarticulados, próprios da literatura fantástica e do mundo do sonho. (ROUDINESCO; PLON, 1998, p.383)

Vale lembrar, então, que o estranho freudiano é algo bem diferente do estranho todoroviano, um gênero vizinho ao fantástico, assim como o maravilhoso. Embora, de certa forma, se interceptem a partir do momento em que ambos "encontram" uma explicação lógica para o fenômeno em questão.

Vimos que o fantástico não dura mais que o tempo de uma vacilação: vacilação comum ao leitor e ao personagem, que devem decidir se o que percebem provém ou não da "realidade", tal como existe para a opinião corrente. Ao finalizar a história, o leitor, se o personagem não o tiver feito, toma entretanto uma decisão: opta por uma ou outra solução, saindo assim do fantástico. Se decidir que as leis da realidade ficam intactas e permitem explicar os fenômenos descritos, dizemos que a obra pertence a outro gênero: o estranho. Se, pelo contrário, decide que é necessário admitir novas leis da natureza mediante as quais o fenômeno pode ser explicado, entramos no gênero do maravilhoso. (TODOROV, 1992, p.24)

Podemos observar que a procura de Freud pelo que causa a impressão do estranho é, de certa forma, análoga a algumas indagações que motivaram teóricos da ficção fantástica, seja na procura do que instaura o fantástico no texto, seja na busca de uma temática específica do fantástico, como o fizeram Callois e Todorov, por exemplo. Temas como o medo, o duplo, o fator da repetição, 
entre outros abordados por Freud, foram largamente estudados por teóricos dos Estudos Literários, em especial da ficção fantástica.

Fato é que vários teóricos do fantástico se valeram não só dos estudos do estranho desenvolvidos por Jentsch e Freud, ambos tendo como base o texto de Hoffmann (2012), como também de outros conceitos desenvolvidos pelo pai da Psicanálise. Até mesmo críticas em relação ao tratamento que Freud dá em seu texto aos personagens (VAX Apud CAMARANI, 2014, p.46), ou discussões a respeito da influência da vida do autor em sua obra (TODOROV, 1992, p.79) serviram de material para debates teórico-críticos na área dos Estudos Literários.

Na obra básica dos estudos do fantástico, Introdução à literatura fantástica do teórico búlgaro, publicada primeiramente em 1970, várias menções são feitas a Freud e à Psicanálise, sofrendo influência decisiva no desenvolvimento das ideias de Todorov, como, por exemplo, a respeito da temática fantástica.

Vimos que os temas do eu podiam interpretar-se como realizações da relação entre o homem e o mundo, do sistema percepção-consciência. Nada disso acontece neste caso: se queremos interpretar os temas do você no mesmo nível da generalidade, deveremos dizer que se trata mas bem da relação do homem com seu desejo e, por isso mesmo, com seu inconsciente. $O$ desejo e suas diversas variações, entre as quais se inclui a crueldade, são outras tantas figuras nas que estão compreendidas as relações entre seres humanos; ao mesmo tempo, a posse do homem pelo que de maneira superficial pode chamar-se seus "instintos" expõe - problema da estrutura da personalidade, de sua organização interna. Se os temas do eu 
implicavam essencialmente uma posição passiva, neste caso se observa, pelo contrário, uma forte ação sobre o mundo circundante; o homem já não é um observador isolado, mas sim participa de uma relação dinâmica com outros homens. Por fim, se foi possível atribuir à primeira rede os "temas do olhar", devido à importância que nele têm a vista e a percepção em geral, terei que falar aqui dos "temas do discurso", já que a linguagem é, em efeito, a forma por excelência e o agente Ihe estruturante da relação do homem com seu próximo. (TODOROV, 1992, p.73- grifo nosso)

No último capítulo do mencionado livro, Todorov chega a levantar a possibilidade de a Psicanálise vir a substituir a literatura fantástica:

Vamos ainda mais longe: a psicanálise substituiu (e por isso mesmo voltou inútil) a literatura fantástica. $\mathrm{Na}$ atualidade, não é necessário recorrer ao diabo para falar de um desejo sexual excessivo, nem aos vampiros para aludir à atração exercida pelos cadáveres: a psicanálise, e a literatura que direta ou indiretamente se inspira nela, tratam-nos com termos diretos. Os temas da literatura fantástica coincidem, literalmente, com os das investigações psicológicas dos últimos cinqüenta anos. Já examinamos numerosos exemplos; bastará mencionar aqui que a dupla personalidade, por exemplo, foi já em épocas de Freud, tema de um estudo clássico [...]. (TODOROV, 1992, p.84)

Aliás, ao contrário do que Todorov (1992) prenunciou, a Psicanálise não substituiu a ficção fantástica, mas veio, talvez, proporcionar novos rumos a ela, e se aliar aos estudos teóricos do fantástico ficcional, como atesta Camarani (2014) ao citar Freud inúmeras vezes em seu livro, justamente por suas ideias se alinharem e servirem de base para vários teóricos, como Louis Vax (VAX, 1965, 
Apud CAMARANI, 2014, p.45-47), Bellemin-Noël (BELLEMIN-NOËL, 1972, Apud CAMARANI, 2014, p.79-84), Valérie Tritter (TRITTER, 2001, Apud CAMARANI, 2014, p.123), Remo Ceserani (CESERANI, 2006, Apud CAMARANI, 2014, p.134) e David Roas (ROAS, 2011, Apud CAMARANI, 2014, p.172), sendo que Tritter e Ceserani também dão especial ênfase a Hoffmann (2012) e a seu Homem da areia.

Isso já atesta a importância de Freud e seu estudo para os teóricos da ficção fantástica, onde a inquietante estranheza, de alguma forma, se faz presente. Além disso, podemos considerar que o ensaio Das Unheimliche, de Freud, inaugurou um diálogo profícuo entre os Estudos Literários e a Psicanálise, criando a chamada crítica psicanalítica. Afinal, trazer luz ao processo criativo e ao sistema de crenças, tanto dos autores quanto dos leitores é, em parte, tarefa das ciências que se ocupam da psique humana, seja a Psicanálise, a Psicologia ou a Psicologia Analítica.

\section{REFERÊNCIAS}

BESSIÈRE, Irène (1974). "Le récit fantastique: forme mixte du cas et de la devinette". In: . Le récit fantastique: La poétique de l'incertain. Paris: Larousse, p.9-29. Biagio D’Angelo (Trad.). Maria Rosa Duarte de Oliveira (Col.). CAMARANI, Ana Luiza Silva (2014). A literatura fantástica: caminhos teóricos. São Paulo: Cultura Acadêmica.

CARVALHO, Bernardo (2011). "O 'Unheimlich' em Freud e Schelling". Revista de Psicanálise Percurso. In http://revistapercurso.uol.com.br/index. php?apg=artigo_view\&ida=866\&ori=autor\&letra=C Acesso em 25.Mai.2018.

CEIA, Carlos (2018). E-Dicionário de termos literários. In http://edtl.fcsh.unl.pt/ Acesso em 16.Fev.2019.

FREUD, Sigmund (1919). "Das Unheimliche". In: Gesammelte Werke. London: Standard. 
(1976). "O estranho". In: Obras psicológicas completas de

Sigmund Freud. Jayme Salomão (Trad.). Rio de Janeiro: Imago, v.17, p.275-314. (2010). "O inquietante". In: . Obras completas. Paulo César de Souza (Trad.). São Paulo: Companhia das Letras, v.14, p.329-376.

FURTADO, Filipe (1980). A construção do fantástico na narrativa. Lisboa: Livros Horizonte.

HOFFMANN, E. T. A. (2012). O homem da areia. Ary Quintella (Trad.). Rio de Janeiro: Rocco Digital.

LAPLANCHE, Jean; PONTALIS, Jean-Bertrand (1991). Vocabulário da psicanálise. São Paulo: Martins Fontes.

NASIO, Juan David (1989). Lições sobre os 7 conceitos cruciais da psicanálise. Rio de Janeiro: Jorge Zahar.

RANK, Otto (2013). O duplo. Porto Alegre: Dublinense.

ROUDINESCO, Elisabeth; PLON, Michel (1998). Dicionário de psicanálise. Rio de Janeiro: Jorge Zahar.

TODOROV, Tzvetan (1992). Introdução à literatura fantástica. São Paulo: Perspectiva. 